\title{
Does investment call the tune? Empirical evidence and endogenous theories of the business cycle
}

\begin{abstract}
José A. Tapia Granados ${ }^{1}$
Abstract: Theories of the business cycle can be classified into two main groups, exogenous and endogenous, according to the way they explain economic fluctuations-either as responses of the economy to factors that are external (exogenous shocks) or as upturns and downturns of the economic system internally generated (by endogenous factors). In endogenous theories investment is generally a key variable to explain the dynamic status of the economy. This essay examines the role of investment in endogenous theories. Two contrasting views on how changes in investment and profitability push the economy toward expansion or contraction are represented by the insights of Kalecki, Keynes, Matthews, and Minsky, versus those of Marx and Mitchell. Hyman Minsky claimed that investment "calls the tune" to indicate that investment is the only variable not determined by other variables, so that future profits, investment, and the dynamic status of the economy are determined by current investment and investment in the near past. However, this hypothesis does not appear to be supported by available empirical data for 251 quarters of the U.S. economy. Statistical evidence rather supports the hypothesis of causality in the direction of profits determining investment and, in this way, leading the economy toward boom or bust.
\end{abstract}

\section{Introduction}

Modern economists often discuss "the business cycle," though some American economists avoid this term and prefer to refer to "economic fluctuations," while British authors generally favor "trade cycle." Indeed, a plethora of terms have been used in economic jargon to refer to this bipolar phenomenon: boom-and-bust cycle, expansion and contraction, upturn and downturn, mania and panic, and prosperity and depression have been among the terms used since the $18^{\text {th }}$ century. Terms such as revulsion in trade, commercial distress, stagnation, slump, recession or crisis were also used in the past to describe the phase of declining business activity of the "cycle."

The so-called Great Recession has stimulated interest in business-cycle theory, in which a major issue is whether there exists a key variable or variables that exerts a major influence on the economy and serves as the major determinant of its dynamic condition of expansion or contraction. Many business-cycle theories claim to answer that question, though the answer is often buried in jargon or mathematical equations. This paper reviews some general aspects on how causes of business cycles have been conceptualized in economic thought, and the views of major theorists of the business cycle are examined, focusing on the role of investment and profits. Empirical evidence is presented and statistical procedures-descriptive statistics, lag regressions, and Granger causality testsare used to test how empirical data fit with some proposed theories.

\section{Some general aspects of business-cycle theories}

The earliest conjectures on the business cycle and depressions were probably the underconsumption theories proposed at the turn of the $18^{\text {th }}$ century by Lord Lauderdale, Tho-

\footnotetext{
${ }^{1}$ SEH/SRC, Institute for Social Research, University of Michigan, Ann Arbor. E-mail: jatapia@umich.edu.
} 
mas R. Malthus, and Simonde de Sismondi. These authors attributed downturns in business activity to economic circumstances, that is, to endogenous factors (Mitchell, 1927: Ch. 1). "General gluts" would occur because purchasing power available in society is not sufficient to buy the output produced, low wages would not allow labor "to buy its own product." These underconsumption theories were however rejected by Jean Baptiste Say, David Ricardo, and most economists of the $19^{\text {th }}$ century, who accepted the idea that sufficient demand is always available to purchase the produced supply. Later baptized as Say's Law, this would be the supposed theoretical reason precluding the possibility of "general gluts."

Haberler's opinion was that underconsumption theories have a scientific standard quite lower than other theories of the business cycle (Haberler, 1960). Schumpeter (1954:740) suggested the same thing, asserting that underconsumption theory, "as Marx well knew, is beneath discussion since it involves neglect of the elementary fact that inadequacy (...) of the wage income to buy the whole product at cost-covering prices would not prevent hitchless production in response to the demand of non-wage earners either for 'luxury' goods or for investment." Of course, Karl Marx also rejected Say's Law, though his reasons for it were quite different from those of Malthus, Sismondi or Rodbertus.

Leaving underconsumption aside, with the weapon of Say's Law at hand the nascent discipline of economics was quite aloof to the possibility of general gluts of markets and thus paid little attention to commercial crises and business-cycle issues. Indeed, apart from Marx and Jevons, economists were scarcely interested in this field (Morgan, 1990:15) and a major contribution such as Les Crises commerciales et leur retour periodique en France, en Angleterre, et aux Etats-Unis came from a non-economist, Clément Juglar, in 1862.

The years between 1870 and the start of World War I saw major developments in economics, where the "cycle" displaced "crises" from economists' minds and crises theories were displaced by business-cycle theories (Besomi, 2005; Schumpeter, 1954:1123). It was also the time when three exogenous theories that attribute business cycles to astronomical or biological influences were proposed. In papers published by W. S. Jevons between 1875 and 1882 and in two books authored by H. L. Moore in 1914 and 1923 the fluctuations of the economy were attributed to weather, determined in turn by astronomical phenomena-sun spots in Jevons's view, the planet Venus in Moore's (Morgan, 1990:1833). In 1920 the geographer Ellsworth Huntington proposed autonomous changes in the rate of death as the factor stimulating or depressing business. When mortality rises, it causes sadness and a drop in spending, which leads to a slowdown of the economy; conversely, a decrease in mortality would cause increasing spending and prosperity. These views, today scarcely considered or even known, are typical examples of exogenous business-cycle theories in which the oscillations between prosperity and depression are attributed to phenomena external to the economy itself.

In the late 1920 s exogenous theories of the business cycle found an unexpected source of inspiration in the work of the Russian statistician Evgeny Slutzky, who showed that applying a linear operator to a series of random numbers could generate apparent cycles. Following Slutzky's idea, Ragnar Frisch (1933) was the first in proposing that the fluctuations of the level of activity in modern industrial economies may be due to the effects of erratic, uncorrelated shocks upon an otherwise interrelated system (Adelman, 1960). Frisch proposed the separation of the impulse problem (the discontinuous shocks providing oscillating energy to the system) and the propagation mechanism (the inner workings of the system, leading it toward equilibrium). In the 1950s Irma Adelman and Frank L. Adelman showed that applying perturbations to the endogenous variables of the propagation mechanism as well as applying random shocks to 'energize' the system en- 
abled the Klein-Goldberger econometric model of the U.S. economy to show oscillations resembling the empirically observed business cycles. In the words of Ira Adelman (1960), she and her husband had not "proved that business cycles are stochastic in origin" though they had presented evidence creating "a strong presumption in favour of this hypothesis" which would be "especially significant in view of the absence (to date) of a completely satisfactory endogenous theory of business cycles."

The view that business cycles are exogenously determined by random shocks strongly influenced economics in the 1960 s and 1970s. Indeed, disputes between Keynesian and monetarist authors during the period of decline of Keynesian economics can be seen as arguments about which parts of the propagation mechanism are either actually working, or the most important for the dynamics of the economy. These disputes were later superseded by rational expectations and assumptions about the intertemporal substitution of leisure for labor.

We arrive to the views of late $20^{\text {th }}$ century macroeconomists supporting the realbusiness-cycle (RBC) theory who conceptualize business cycles as the consequence of a self-equilibrating economy responding to random events affecting aggregate supply. They often mention, in the tradition of Schumpeter and Hayek, technological innovations or "shocks" as causes of economic fluctuations. Other exogenous factors such as demographic changes, political influences, or variations in relative prices have been also proposed. This type of "supply shocks" is often referred to without specifying its nature, though for instance James Hamilton $(1988,1994)$ proposed changes in oil prices as a key determinant of recessions.

Nowadays, however, economists supporting a theory of business cycles determined by exogenous factors-Austrians, monetarists, RBC theorists- are probably a minority compared to economists who view the fluctuations of the market economy as mainly determined by endogenous factors-Samuelsonians, Keynesians, new-Keynesians, postKeynesians, institutionalists and socialist economists. ${ }^{2}$ At any rate, as Thomas E. Hall put it twenty years ago, it is important to keep in mind the distinction between endogenous and exogenous theories, "because they imply a very different behavior for an economy." Those supporting exogenous factors as causes of the business cycle tend "to view economies as being inherently stable but shocked by outside forces" while endogenous theorists "generally consider economies as being inherently unstable and subject to selfgenerating cycles. This distinction in macroeconomics is very old and exists today between the monetarists (primarily exogenous) and Keynesians (primarily endogenous)" (Hall, 1990:10).

Wages are a key variable explaining recessions for many economists. However, authors agreeing with this claim adhere to quite different schools of thought and have proposed diverse, indeed opposite mechanisms to explain why changes in wages would cause economic downturns. Both too high or too low wages have been viewed as causes of recession.

In the view of Arthur Pigou (1927) presented recently for example by Lee Ohaniann (2008), a qualified representative of the RBC school, it is too high wages that cause too high costs for business, with the consequent decay in economic activity leading to a downturn. Consequently, in this view a decrease in wages would increase supply and would also have a stimulating effect on economic activity. A different perspective is offered by those who from a variety of theoretical positions support the so-called profitsqueeze hypothesis (Boddy and Crotty, 1975; Boldrin and Horvath, 1995; Bhaduri and Marglin, 1990) in which high wages lead to recession through the demand side. The

\footnotetext{
${ }^{2}$ For a modern survey of theories of the business cycle see Knoop (2004). The encyclopedia edited by Glasner and Cooley (1997) is a wealth of information.
} 
pathway would be here from high wages to low profits, and from low profits to falling investment and the lack of effective demand with unsold goods that characterizes recessions. Some authors who support the profit-squeeze hypothesis also seem to hold underconsumptionist views, since they deemphasize the role of investment in business cycles by claiming that, with a "relatively weak response of investment to profitability (...), consumption necessarily assumes the dominant role in effective demand" (Bhaduri and Marglin, 1990). In a purely underconsumptionist view too low wages generating too low purchasing power for consumer goods reduce aggregate demand and cause recession, so that an increase in wages during a slump would tend to stimulate recovery.

\section{Investment leads (I): Kalecki and Keynes}

It is a common view today that Michał Kalecki independently discovered many elements of what later would be called Keynesian theory. Many would even agree that Kalecki's construct is superior to that of Keynes in crucial aspects. At any rate, as we will see, for both Keynes and Kalecki, and for the whole Keynesian school, investment is the key variable explaining macroeconomic dynamics, and leading the cycle.

In the early years of the Great Depression Kalecki published several articles in Przeglą Socjalistyczny, an independent Polish "Socialist Review." Signing as Henryk Braun, Kalecki (1990:37-53) commented on different aspects of the world financial crisis. ${ }^{3}$ In one of the articles he referred to Keynes as "a representative of British imperialism" and "possibly the leading bourgeois economist" (Kalecki, 1990:45-47). In "Is a capitalist' overcoming of the crisis possible?" (1932), Kalecki argued that during a crisis investment shrinks and

it is precisely here that one should seek the starting-point of processes that will bring an upswing of the business cycle. Owing to the fact that during a crisis investment activity is at a lower level than that required for simple reproduction (maintenance) of the existing capital equipment, thus equipment is also gradually depleted. Unused and outdated machines are sold for scrap and new ones are not purchased to replace them. Besides, a considerable number of machines-and equipment in general-still kept in factories has not been reconditioned nor maintained properly, and may have become obsolete as well (due to technological progress), and is therefore only partially usable. On the other hand, since in a certain phase of the crisis the output of consumer goods generally starts declining more slowly than the rate of this contraction of capital equipment, there is a real need to employ the existing equipment more fully, which in turn requires investment. There is then a better chance of intensifying investment activity, which is the basic foundation for overcoming the crisis (...). In the final analysis (...) of those components of the mechanism of the capitalist economy which could form a foundation for overcoming the crisis, the contraction of capital equipment caused by the decline of investments (and also by the running down of stocks) should be put in first place (...) Finally, we should mention yet another possibility, namely a certain form of inflation consisting of individual states, or groups of states, starting up major public-investment schemes, such as construction of canals or roads, and financing them with government loans floated on the financial market, or with special government credits drawn on their banks of issue. This kind of operation could temporarily increase employment, though on the other hand it would retard automatic, 'natural' adjustment processes which might lead to overcoming the crisis (Kalecki, 1990:51-53).

These views reveal that Kalecki had already developed a highly elaborated theory of the business cycle in 1932. Kalecki's theoretical scheme was further developed in a book-

\footnotetext{
${ }^{3}$ Kalecki had no academic degree, since he had never finished his engineering studies. He had been earning his living as an economic journalist and working as an analyst for the Polish Institute for the Study of Business Cycles and Prices (ISBCP). This probably explains why he published in the Socialist Review under a pseudonym.
} 
let titled Próba teorii koniunktury, "Essay on the business cycle theory," that was published by the ISBCP in 1933, the same year that Kalecki presented his views on the business cycle in a congress of the Econometric Society. In 1935 abbreviated translations of his booklet were published in Econometrica and Revue d'économie politique. In 1936 Kalecki was planning to write a general exposition of his macroeconomic ideas in a book, until he read Keynes's General Theory. It was the book Kalecki was planning to write, and he felt deeply disappointed for having been beaten to it by Keynes (Shackle, 1967:127).

In chapter 22 of The General Theory Keynes considered the business cycle

as being occasioned by a cyclical change in the marginal efficiency of capital, though complicated, and often aggravated by associated changes in the other significant short-period variables of the economic system (Keynes: 1936, p. 313).

For Keynes the marginal efficiency of capital is the expected rate of return of capital. In terms of $19^{\text {th }}$ century political economy, it is the expected rate of profit, and for Keynes it depends "not only on the existing abundance or scarcity of capital-goods and the current cost of production of capital-goods, but also on current expectations as to the future yield of capital-goods" (p. 315).

Considering the view that the crisis, "the substitution of a downward for an upward movement tendency that often takes place suddenly and violently," may be due to too high levels of the rate of interest, Keynes claimed that "a more typical, and often the predominant, explanation of the crisis is, not primarily a rise in the rate of interest, but a sudden collapse in the marginal efficiency of capital." But why the marginal efficiency of capital-the expected profitability-would fall suddenly after it had been steadily rising or at least remaining stable during the boom? What Keynes says is that as long as the boom

was continuing, much of the new investment showed a not unsatisfactory current yield. The disillusion comes because doubts suddenly arise concerning the reliability of the prospective yield, perhaps because the current yield shows signs of falling off (...) Once doubt begins it spreads rapidly (p. 317).

Keynes suggests that the fall in expectations about profitability may be perhaps caused by the declining current yield. He does not seem to put much faith in that explanation, however, because during the crisis

it is not so easy to revive the marginal efficiency of capital, determined, as it is, by the uncontrollable and disobedient psychology of the business world. It is the return of confidence, to speak in ordinary language, which is so insusceptible to control in an economy of individualistic capitalism. This is the aspect of the slump which bankers and business men have been right in emphasising, and which the economists who have put their faith in a "purely monetary" remedy have underestimated (p. 317).

From the dependence of the trade cycle on the psychology of investors, Keynes concluded that in conditions "of laissez-faire the avoidance of wide fluctuations in employment may, therefore, prove impossible without a far-reaching change in the psychology of investment markets such as there is no reason to expect" (p. 320).

One year after The General Theory appeared Keynes clarified in the Quarterly Journal of Economics some of the issues that had been raised by the book. For Keynes his theory could be summed up "by saying that, given the psychology of the public, the level of output and employment as a whole depends on the amount of investment" [my italics, JATG]. Keynes was explaining his theory this way "not because this is the only factor on which aggregate output depends, but because it is usual in a complex system to regard 
as the causa causans that factor which is most prone to sudden and wide fluctuation" (Keynes, 1937).

Kalecki reviewed The General Theory in the Polish journal Ekonomista in 1936, praising it as "a turning point in the history of economics." For Kalecki the book had two main components, one discussing the mechanisms determining a short-period equilibrium once the level of investment was given, the other dealing with the determination of the level of investment. Keynes, Kalecki said, had reasonably succeeded in the former, but had failed in the latter. Kalecki agreed that

investment is the factor which decides the short-period equilibrium, and hence, at a certain moment, the size of employment and of social income. In fact the volume of investment will decide the amount of the labour force which will be absorbed by the existing production apparatus (Kalecki, 1990:228).

Kalecki saw serious deficiencies in Keynes's belief that the level of investment would be determined by the equalization of expected profitability and the rate of interest. This would not lead to equilibrium, but to a continuous process in which higher investment led to a never-ending process of higher expected profitability which in turn raises investment:

Keynes's concept (...) meets a serious difficulty along this path also. In fact, the growth of investment in no way results in a process leading the system toward equilibrium. Thus it is difficult to consider Keynes's solution of the investment problem to be satisfactory. The reason for this failure lies in an approach which is basically static to a matter which is by its nature dynamic. Keynes takes as given the state of the expectations of returns, and from this he derives a certain definite level of investment, overlooking the effects that investment will in turn have on expectations. It is here that one can glimpse the road one must follow in order to build a realistic theory of investment. Its starting-point should be the solution of the problem of investment decisions, of ex ante investment. Let us suppose there to be, at a given moment, a certain state of expectations as to future incomes, a given price level of investment goods, and, finally, a given rate of interest. How great then will be the investment that entrepreneurs intend to undertake in a unit of time? Let us suppose that this problem has been solved (despite the fact that it seems impossible to do this without introducing some special assumptions on the psychology of entrepreneurs or on money market imperfections). A further development of the theory of investment could be as follows. The investment decisions corresponding to the initial state will not generally be equal to the actual volume of investment. Therefore, in the next period the volume of investment will generally be different and the short-period equilibrium will change together with it. Hence we should now deal with a state of expectations that in general will be different from that of the initial period, different prices of investment goods, and a different rate of interest. From these a new level of investment decisions will result-and so on (...) Keynes did not explain precisely what causes changes in investment, but, on the other hand, he has fully examined the close link between these changes and global employment, production, and income movements (Kalecki, 1990:230-232).

Keynes likely never knew about this review, which was only translated into English in the 1980s. But in the late 1930s Kalecki went to England and forged an awkward intellectual relationship with Keynes, eventually gaining his respect.

According to Steindl (1991:597), Kalecki published three versions of his theory of the business cycle, corresponding roughly to his 1933 booklet, his 1954 Theory of Economic Dynamics, and his late works. Though the relation between profitability and investment is explained in slightly different terms in each version of the theory, it remained substantially unchanged in its main aspects. In his 1933 booklet Kalecki presented profitability as the variable "that stimulates the desire to invest. This is entirely consistent with reality, since the incentive to invest is expected profitability, which is estimated on the basis of the profitability of existing plants" (Kalecki 1990:68). However, investment or con- 
sumption of some capitalists creates profit for others and, as a class, capitalists "gain exactly as much as they invest or consume" so that capitalists "determine their own profits by the extent of their investment and personal consumption (Kalecki 1990:79). In Theory of Economic Dynamics (1954) Kalecki wrote that capitalists "can decide to consume and invest more in a given period than in the preceding period, but they cannot decide to earn more. It is therefore, their investment and consumption decisions which determine profits, and not vice versa" (Kalecki 1991:240). Profits "in a given period are the direct outcome of capitalist consumption and investment in that period" (Kalecki 1991:244). More formally, profits at a time $t$ are a linear function of investment at time $t$ and previous times $t-\lambda$; profits "will thus be a function both of current investment and of investment in the near past; or roughly speaking, profits follow investment with a time lag" (Kalecki 1991:247). In turn, "investment at a given time is determined by the level and rate of change in the level of investment at some earlier time" (Kalecki 1991:292). The final version of the Kaleckian theory of the business cycle would be the one presented in his publications of the late 1960s. In "The Marxian equations of reproduction and modern economics" (1968) Kalecki again presented investment and capitalist consumption as the independent variables that determine the levels of national income and profits (Kalecki 1991:461). In the introduction to Selected Essays on the Dynamics of the Capitalist Economy, 1933-70, published posthumously in 1971, Kalecki explained that the theory of economic demand that he had formulated in the 1930s had remained unchanged; however "there is a continuous search for new solutions in the theory of investment decisions." But he included in the book his theory of profits of 1954, restating his view that it is "investment and consumption decisions which determine profits, and not vice versa" (Kalecki 1971:79).

According to Asimakopulos (1977:329), Kalecki "emphasized a double-sided relation between investment and profits." It is true that in a number of places Kalecki argues that investment depends on profits, or that profitability stimulates investment. He argues for instance that the rate of investment decisions is influenced by the increase in profits per unit of time, so that rising profits "from the beginning to the end of the period considered renders attractive certain projects which were previously considered unprofitable, and thus permits an extension of the boundaries of investment plans in the course of the period" (Kalecki, 1991:282). For Asimakopulos (1977:339) Kalecki poses current investment as predetermined by past decisions, and through its effects on sales and profits contributing to determine expected profitability. In turn, this expected rate of profit influences, along with other factors, the investment decisions made in this period for implementation in future time periods. Even in this presentation, however, investment is the causa causans, while profits are just an intermediate link in the causal chain. Considering the major works in which Kalecki presented his macroeconomic theory, it is difficult to disagree with the way Targetti and Kinda-Hass (1982:254) put it: "the levels of profits at a certain date is entirely and solely determined by past decisions to invest." Even allowing for subtleties, in Kalecki the determination is from investment to profits, and in the relation there is little room, if any, for reverse causation.

\section{Investment leads (II): The Keynesian school}

Since The General Theory presented a theory of comparative statics, though containing key elements to develop a dynamic theory (Robinson, 1979), it was left for economists following Keynes's tradition to develop such a theory, that is, a Keynesian theory of the business cycle. Leaving aside Kalecki, The Trade Cycle by Robin C. O. Matthews, published in England in 1959 and republished in the United States as The Business Cycle, it can arguably be considered one of the first systematic examinations of business cycle 
theory from an explicitly Keynesian point of view. ${ }^{4}$ Judging by the authors cited and the ideas discussed, it seemed that Matthews was open-minded toward recent ideas of Paul Samuelson, J. R. Hicks, Milton Friedman and others that were making powerful inroads in economics in the 1950s. The general perspective of the book, however, is plainly Keynesian. Matthews repeatedly also cited Michal Kalecki's Theory of Economic Dynamics, at that time the most recent presentation of Kalecki's macrodynamic ideas.

Mathews opened his book with a discussion of the variables that may produce an imbalance between aggregate demand and aggregate supply. When briefly mentioning Slutsky's views on recessions being the consequence of the economy responding to random shocks of a diverse character, Matthews commented that statistical data indicate

that economic fluctuations are not due solely to random factors, and it is also clear both from an a priori reasoning and from our more detailed knowledge of history that certain forces do operate which are in principle capable of causing fluctuations of a systematic character (p. 202, italics in the original).

According to Matthews:

The doctrine that consumption expenditure depends principally on the level of national income is one of the foundations of Keynesian economics. It is because of this doctrine that the other main component of national income, investment, is regarded as the prime mover in fluctuations in national income, the role of consumption being a passive one (p. 113).

To discuss the basic determinants of investment must therefore be a key aspect of the theory of the business cycle. In this respect, the major consideration

affecting the inducement to do investment is profitability. Investment will be done if the expected profits represent an adequate return on the sum spent. The physical relation between output and capital is important only in so far as it influences the expected rate of return on investment (p. 34).

In other words,

the basic postulate is that the amount of investment done is a function of the expected rate of return. If conditions are such as to promise a high rate of return, much investment will be done, and conversely. There will be a certain critical level of expected returns at which zero net investment is done (p. 36).

Matthews meticulously considered the relation of investment with competition, technical progress, animal spirits, finance, inventories and home construction. His conclusion was that

the chief reason for the waves of high and low investment that are the essence of the cycle is the existence of a cumulative effect by which if investment in any period is high relative to its long-run trend value, it encourages investment in the next period to stay high or to rise further, up to a point, while if investment is low it likewise discourages investment in the next period ( $p$. 82).

This means that with appropriate investment the economy would grow without interruption, and slumps would be avoided:

If entrepreneurs can only screw themselves up to do enough investment, it will eventually justify itself, since the income generated will absorb the excess capacity (p. 178).

\footnotetext{
${ }^{4}$ Business Cycles and National Income (Hansen, 1964), first published in 1959, could also lay claim to that distinction.
} 
A comparison of the theories of the business cycle in Matthews's Trade Cycle and in Hyman Minsky's Stabilizing an Unstable Economy, written and published three decades later, reveals many common views but also some major differences in emphasis and even in conception. Both Matthews and Minsky were self-professed Keynesians, but Minsky's view of economic fluctuations emphasized the financial factors creating economic disturbances and leading to financial crises and recessions, while Matthews was quite adamant that business cycles are phenomena mostly related to the real economy, in which their causes need to be examined. For Matthews it was an outdated view

that the causes of fluctuations lay wholly or largely in the sphere of money and finance. The trend of opinion has now swung in the opposite direction. Most modern theoretical treatments of the cycle are based on an analysis of real forces, and it is implicitly assumed that secondary importance, at most, attaches to any effects that may be brought about by changes in the cost and availability of finance (Matthews, 1959:128).

After a detailed discussion of factors leading to speculation and bubbles in different markets, Matthews had concluded that financial crises generally occur after the downturn in the real economy has already started, so that the financial crisis may aggravate the downturn but does not cause it. The contrast is patent with the main thrust of Stabilizing an Unstable Economy, where Minsky emphasizes the role of financial factors and criticizes the neoclassical synthesis for its inability to recognize that "the instability so evident in our economy is due to the behavior of financial markets, asset prices, and profit flows" (Minsky, 2008:156).

According to Minsky, a basic aspect of modern capitalism is that past financing of investment leaves a legacy of payment commitments, and for these commitments to be fulfilled the income of indebted investors must be sufficient. The price system must therefore

generate cash flows (...) which simultaneously free resources for investment, lead to high enough prices for capital assets so that investment is induced, and validate business debts. For a capitalist system to function well, prices must carry profits (p. 158, Minsky's italics).

The determinants of profits is thus a key issue, and Minsky (p. 184, italics in the original) concludes that

Investment and government spending call the tune for our economy because they are not determined by how the economy is now working. They are determined either from outside by policy (government spending) or by today's views about the future (private investment).

Causality, then, "runs from investment and government spending to taxes and profits" and in recessions

Big Government, with all its inefficiencies, stabilizes income and profits. It decreases the downside risks inherent in a capital-intensive economy that has a multitude of heavily indebted firms (p. 186).

Investment is therefore the basic determinant of the dynamic status of the economy. To look for economic factors causing investment to rise or fall is beside the point, since the present level of investment determines the present level of income and the future level of profits and investment. In the colorful words of Minsky, Government spending and investment "call the tune." Only the psychological sphere of expectations remains as the source of investment fluctuations. Given adequate investment, profits will rise and the economy will grow. 
It is investment, then, which in the view of Kalecki, Keynes and the Keynesians "calls the tune" by determining profits and thus leading the business cycle. 5

\section{Profits led: Marx and Mitchell}

Karl Marx and Wesley Mitchell are infrequently cited in modern discussions on macroeconomic issues, perhaps because compared with predominant neoclassical or Keynesian views they provide quite a different perspective on the ways our economy works. Marx and Mitchell share with the Keynesian school the view that investment, or capital accumulation in Marx's terminology, is a key variable in economic dynamics. ${ }^{6}$ However, neither Marx nor Mitchell attributes to investment the major causal role in business cycles, because they see investment as depending itself on profitability.

Marx's analysis of the business cycle has been considered an unwritten chapter and "no coherent picture of it has emerged, or is likely to emerge, that would command the approval of all Marxologists" (Schumpeter, 1954:747). Though this is still probably true, some elements of that analysis are not controversial. What Marx called the industrial cycle-in which periods of capital accumulation alternate with crises-is mostly discussed in manuscripts that were posthumously published. In one of them Marx wrote for instance that the rate at which the capital is valorized, i.e., the rate of profit, "is the spur to capitalist production (in the same way as the valorization of capital is its sole purpose)," so that a decline in this rate "slows down the formation of new, independent capitals and thus appears as a threat to the development of the capitalist production process; it promotes overproduction, speculation and crises" (Marx, 1981:348-349). In his notebooks published as Theories of Surplus Value Marx asserted that accumulation is determined "by the ratio of surplus-value to the total capital outlay, that is, by the rate of profit, and even more by the total amount of profit" (Marx, 1968:542).

Explicit insights on business-cycle theory are also given in the only volume of Capital that Marx published himself in 1867 (Marx, 1977). There, in the chapter on "the general law of capitalist accumulation" Marx stated that the characteristic evolution of modern economies is typically a decennial cycle in which periods of average activity are followed by production at high pressure, crisis, and finally stagnation. Periods of capital accumulation (that is, economic expansions with high levels of investment) are characterized by an increased demand for labor power. During the cycle there is a constant formation, absorption, and re-formation of a mass of unemployed workers-the "industrial reserve army." This mass of unemployed workers

during the periods of stagnation and average prosperity, weighs down the active army of workers; during the periods of over-production and feverish activity, it puts a curb on their pretensions (p. 792).

Periods of capital accumulation are the most favorable for workers in terms of income, because a larger part of the surplus-product of industry, which is

\footnotetext{
${ }^{5}$ That major differences exist among authors pertaining to this tradition exist is exemplified by a comment of the editor of Kalecki's Collected Works, Jerzy Osiatynski, who says that in Kalecki's Theory of Economic Dynamics "the long-run development of the capitalist economy, and even its passage to the phase of the business upswing, was only possible under the influence of exogenous factors" (my emphasis, JATG., Kalecki 1991:551). This sharply contrasts with assertions by Minsky, who claiming to follow Kalecki's views on economic dynamics argued however that cycles and crises "are not the result of shocks to the system or of policy errors, they are endogenous" (Minsky, 1991).

${ }^{6}$ For Marx capital accumulation takes place when money profits are spent in purchasing capital goods (constant capital in Marxian parlance) or paying wages (variable capital) to expand production. In that respect the Marxian concept of capital accumulation is wider than the concept of "investment" in national accounts and mainstream economics, which usually refers to purchase of capital goods.
} 
increasing and is continually transformed into additional capital, comes back to them in the shape of means of payment, so that they can extend the circle of their enjoyments, make additions to their consumption fund of clothes, furniture, etc., and lay by a small reserve fund of money (p. 796).

The tightness of the labor market during periods of capital accumulation (that is, upturns) will likely produce a rise in wages, and then two things can happen:

Either the price of labour keeps on rising, because its rise does not interfere with the progress of accumulation (...) Or, the other alternative, accumulation slackens as a result of the rise in the price of labour, because the stimulus of gain is blunted. The rate of accumulation lessens; but this means that the primary cause of that lessening itself vanishes (...) The mechanism of the process of capitalist production removes the very obstacles that it temporarily creates ( $p$. 770).

In this passage investment is portrayed as a function of profitability when reference is made to accumulation slackening "because the stimulus of gain is blunted." On the other hand, a profit-squeeze mechanism is also suggested, since Marx admits that rising wages might cut profits and in this way induce a fall in the rate of investment that triggers a downturn. Though this is offered as a possibility, Marx seems to reject the implied causal pathway as an important one, because he asserts later in the same paragraph that

To put it mathematically: the rate of accumulation is the independent, not the dependent, variable; the rate of wages, the dependent, not the independent, variable.

Profit is for Marx the monetary translation of unpaid labour supplied by the working class to the owners of capital. When profit

accumulated by the capitalist class increases so rapidly that its transformation into capital requires an extraordinary addition of paid labour, then wages rise, and, all other circumstances remaining equal

profit diminishes. But as soon as this diminution reaches the point at which profit that nourishes capital

is no longer supplied in normal quantity, a reaction sets in: a smaller part of revenue is capitalized, accumulation slows down, and the rising movement of wages comes up against an obstacle. The rise of wages therefore is confined within limits that not only leave intact the foundations of the capitalist system, but also secure its reproduction on an increasing scale ( $p$. 771).

Marx emphasized the idea that accumulation depends on profitability. He did so, for instance, by quoting the opinion of the English trade-unionist Thomas Dunning, who had written that capital

eschews no profit, or very small profit, just as Nature was formerly said to abhor a vacuum. With adequate profit, capital is very bold. A certain $10 \%$ will ensure its employment anywhere; $20 \%$ certain will produce eagerness; $50 \%$, positive audacity; $100 \%$ will make it ready to trample on all human laws; $300 \%$, and there is not a crime at which it will scruple, nor a risk it will not run, even to the chance of its owner being hanged. If turbulence and strife will bring a profit, it will freely encourage both (p. 926).

Wesley Mitchell is quite a different case. If Marx rejected what he called bourgeois political economy from his first intellectual contributions and was paid in kind with a plain rejection from academic economists, Mitchell was throughout his long intellectual life a highly-respected member of the economic profession. He taught economics in prestig- 
ious universities, served for decades as a leading member of the National Bureau of Economic Research, and was president of the American Economic Association. However, in the 1950 o his views on the business cycle were considered atheoretical, and soon after his death his work disappeared into oblivion. ${ }^{7}$

Despite the view that Wesley Mitchell's contributions lacked theory, the reality is that Mitchell had presented quite elaborate views on the causes of expansions and recessions (that is, a theory of the business cycle) as early as 1913 in his voluminous Business Cycles (Mitchell, 1913). Part III of Business Cycles was republished in 1941 as Business Cycles and Their Causes. In his posthumous and unfinished What Happens during Business Cycles, Mitchell briefly restated his views on the causes of the business cycle, which had changed very little since his 1913 book. He still viewed the cycle as a continuous endogenous development, with recession processes leading to expansion, and expansion processes leading into recession. Investment had a key role in the transitions from expansion to recession and vice versa. Though capital goods, Mitchell noted, "form less than $18 \%$ of the gross national product, their output is subject to such violent alternations (...) that this minor segment of the economy contributes $44 \%$ of the total cyclical fluctuation in output, and nearly half of the cyclical declines" (Mitchell, 1951:153).

For Mitchell profits had a major role in economics in general and in business cycles in particular. This was probably the result of both his empirical studies of business and economic life and his acquaintance with Thorstein Veblen, one of the proponents, according to Mitchell himself, of the theory that profit is the key variable explaining economic fluctuations (Mitchell, 1927:42-44). The Veblenian influence seems clear in Mitchell's view of what he called "the money economy," the organization of the modern industrial society in which the bulk of economic activity takes place through the activities of institutions-enterprises-that perform with the purpose of producing money profit. Mitchell said that where the money economy predominates that is, where economic activity takes the form of making and spending money incomes,

natural resources are not developed, mechanical equipment is not provided, industrial skill is not exercised, unless conditions are such as to promise a money profit to those who direct production (Mitchell 1913:21-22).

In one of his late contributions Mitchell insisted in the centrality of money profits for understanding business cycles:

Since the quest for money profits by business enterprises is the controlling factor among the economic activities of men who live in a money economy, the whole discussion [of expansions and recessions] must center about the prospects of profits. On occasion, indeed, this central interest is eclipsed by a yet more vital issue-the avoidance of bankruptcy. But to make profits and to avoid bankruptcy are merely two sides of a single issue-one side concerns the well being of business enterprises under ordinary circumstances, the other side concerns the life or death of the same enterprises under circumstances of acute strain (Mitchell 1941, Preface).

In Mitchell's endogenous view of the business cycle during the phase of prosperity the very conditions "which make business profitable gradually evolve conditions which

\footnotetext{
${ }^{7}$ It was Tjalling Koopman who first presented that criticism in his review (Koopmans, 1947) of Measuring Business Cycles (Burns and Mitchell, 1946). The accusation was echoed by Robert A. Gordon (1961). From Keynesian quarters Alvin Hansen (1949) asserted that "the driving forces back of the cycle movement, Mitchell was never able to disclose". The view of a Marxist economist was also that Mitchell described the "ups and downs [of the economy] using little theory" (Devine, 1986).
} 
threaten a reduction in profits" (Mitchell, 1913:502). Though economic downturns often start with a financial crisis in which banks, insurance companies, and other financial firms go bankrupt, these financial phenomena are preceded by processes that encroach profits in the real economy, at least in a score of major enterprises or industrial sectors. The various stresses rising costs and putting caps on revenue, and thus limiting profits

become more severe the longer prosperity lasts and the more intense it becomes, and since a set-back suffered by any industry necessarily aggravates the stress among others by reducing the market for their products, a reduction in the rate of profits (my italics, JATG) must infallibly occur (...) if an average rate of profits could be computed for a whole country, it would not be surprising to find it reaching its climax just before the crisis breaks out. But this result would not mean that there had been no serious encroachment upon profits. On the contrary, it would mean that the critical point is reached and a crisis is precipitated as soon as a decline of present or prospective profits has occurred in a few leading branches of business and before that decline has become general (Mitchell's italics, p. 503).

But the key variable in downturns is investment, led itself by profitability. Rejecting underconsumptionist explanations that view insufficient demand for consumption goods as the trigger of downturns, Mitchell explained that in the late phases of prosperity

the impossibility of defending profits against the encroachments of costs is experienced earlier by enterprises which handle raw materials and producers goods (...) The technical journals usually report that the factories and wholesale houses are restricting their orders some weeks, if not months, before they report that retail sales are flagging (p. 502).

The decline in profitability in some parts of the economy creates financial strain and reduced sales in other industries, all of which in turn would reduce the incentive to maintain or increase inventories. Investment in wages, raw materials, and new machines or production facilities also falls, which eventually reduces the level of business activity, since business failures and reduction of business activity cut both wages and investment, the two basic sources of demand. This vicious cycle would then operate for months or years, sending the economy into a minor or major recession or depression. Eventually the "very conditions of business depression beget a revival of activity," favorable conditions for investment are newly created and the economy starts expanding again (Mitchell 1913:452). This is so because immediately after a depression

within large groups of enterprises or industries, the rate [of profit] rises promptly with the tide of prosperity (...) Indeed it is certain in particular cases and probable on the average that profits begin to pick up before the period of depression is over (p. 469).

This will increase the volume of investment since in such a situation of business revival

the prospect of good profits leads not only to greater activity among the old enterprises, but also to extensions of their size and to the creation of new enterprises. This expansion of business undertakings is the more important because for a time at least it impacts new energy to the very causes which produced it" (p. 471).

For both Marx and Mitchell rising (or falling) profitability is the key determinants, via investment, of prosperity (or depression).

\section{Empirical evidence}

Any cursory examination of economic statistics shows that the main element of aggregate demand fluctuating upward during expansions and downward during recessions is investment, while consumption varies little between expansion and recession (Mitchell 1951, Sherman and Kolk 1997). Indeed, as Richard Goodwin once explained, the early 
efforts in econometric research on the business cycle were the pair of monographs written by Tinbergen in 1939 for the League of Nations. On the basis of general agreement among economists, Tinbergen selected investment as the crucial cycle variable to be explained (Goodwin, 1964).

For Keynes, Kalecki, Mathews, Minsky, Marx and Mitchell, investment and profits are the key variables explaining the dynamics of the capitalist economy. However, in terms of causation from the Keynesian-Kaleckian perspective, investment is the key variable that determines profits while for Marx and Mitchell, the direction of causality is the opposite, with profits determining investment. Does the empirical evidence support either of these views more than the other?

\subsection{Rates of growth of income flows}

The mean flows of income components during phases of the business cycle, and in the vicinity of its turning points (table 1), give us insight on how major economic variables change during macroeconomic fluctuations and illustrate the role that these variables may have in the generation of the cycle. NIPA data corresponding to 251 quarters of the U.S. economy show, for instance, that capital income, i.e., profits-either before or after taxes-, is much more volatile than labor income, as represented by wages and salarieseither with or without supplements. During expansions profits increased on average $1.9 \%$ per quarter, while wages and salaries rose $1.1 \%$ and $1.0 \%$, respectively, with and without supplements; fixed investment grew $1.3 \%$ per quarter. In recessions all these flows reverse into negative growth, with profits falling 3.9\% per quarter before taxes and $3.1 \%$ after taxes, private investment falling $1.3 \%$, and wages and salaries without supplements falling $0.4 \%$ per quarter. ${ }^{8}$

More interesting, however, is to examine the evolution of income flows in the vicinity of turning points. Corporate profits stop growing, stagnate, and then start falling a few quarters before the recession. Profits before taxes on average grow 1.7\% in the fifth quarter before the start of the recession, but then drop $0.4 \%$ in the next quarter and basically continue decreasing slowly until they plummet in the quarter immediately previous to the recession and during the recession itself (in which, on average, profits before taxes drop almost $4 \%$ per quarter). It seems as if the drop of profits about a year before the recession erupts sends a signal for managers and entrepreneurs to cut investment, because the drop in the rate of growth of profits before taxes (from $4.3 \%$ to $1.7 \%$ and then $-0.4 \%$ ) from the seventh to the fifth quarter before the recession is coupled with a substantial decrease in the rate of growth of investment (from $2.2 \%$ to $0.7 \%$ and then $0.2 \%$ in the same quarters). It may perhaps be that this decrease in investment avoids further losses to some extent, because in the second quarter before the recession profits stop falling and grow again at $0.2 \%$. However, this is just a temporary step on the brake, because profits before taxes drop almost $2 \%$ the quarter immediately previous to open recession and almost $4 \%$ per quarter in each of the quarters of the recession.

On average, private fixed investment continues growing in this pre-recession period, however, and only one quarter before the peak investment starts falling. Wages and salaries continue growing even during the quarter immediately preceding the recession, and they only start declining during the recession itself.

\footnotetext{
${ }^{8}$ Kalecki pointed out that salaries in national income accounts include both salaries of government officials_- which are paid from tax-revenues — and salaries of top-level executives — which are rather akin to profits (Kalecki, 1991:237, fn. 17). For the sake of simplicity it is assumed here that NIPA "wages and salaries" correspond to labor income. Indeed the referred salaries probably tend to increase in nominal terms during expansions more than wages, while in recessions they probably tend to decrease less than wages.
} 
Once the recession ends, the recovery of profits is quick, with a quarterly increase between $9 \%$ and $11 \%$-considering profits before or after taxes-in the quarter immediately following the recession. In that same quarter, however, wages grow at a very small rate, quite below $1 \%$, while investment grows quite intensely at a rate of $3.7 \%$.

These figures do not seem to support the idea that causality runs from investment to profits, since on average profits reverse their growth and start falling several quarters before investment does. This is also applicable to recent recessions. For instance, preceding the recession that started in the fall of 2007 investment peaked in a kind of plateau that lasted from the second quarter of 2006 until the third quarter of 2007. However, profits had peaked in the first quarter of 2006 and then had steadily dropped in the rest of the year (Figure 1). In the long expansion of the 1990s profits started declining long before investment did (profits peaked in 1997:III while investment did in 2000:IV), and the same seems to have occurred in the expansions of the early 1970 s and late 1970 s (Figure 2). In all these cases profits peak several quarters before the recession, while investment peaks almost immediately before the recession. Then the investment trough after the recession is lagged with respect to the profit trough (Figure 2). These facts do not seem compatible with causation going from investment to profits. If the recovery of profits after a slump were dependent on a recovery of investment, some lag would exist for investment spending to be translated into increased profits for firms selling either (a) capital goods to other firms or (b) consumer goods to wage workers hired as the result of new investment (if, as it seems to be, rising private fixed investment correlates with an increase in hiring). But the graphs do not suggest that lag and as we will see the regression analysis do not provide any evidence of such a lag in the data. The observable lag is from changes in profitability to changes in investment.

\subsection{Regression analysis}

Another way to explore this issue is to test how changes in investment predict changes in profits, and vice versa. We can explore these relations by regressing the rates of growth of a variable on present and lagged values of the rate of growth of the other variable. 9

Regression models show that the change in profits, particularly profits before taxes (table 2, panel I), predicts to a significant extent the change in investment, while the change in investment does not predict the change in profits (table 2, panel III). Considering the model that minimizes the Akaike information criterion (AIC), profits before taxes during the present quarter and the five former quarters have a very significant and positive effect on investment, with $44 \%$ of the variation in investment explained by the variation in profits (table 2, panel I, model F). ${ }^{10}$ Profits after taxes during the present quarter and previous quarters also have a noticeable effect on investment, but the effect is much weaker and, compared with profits before taxes, the proportion of change in investment explained is considerably reduced, from $44 \%$ to $32 \%$ (for model $\mathrm{G}$, the one minimizing AIC in panel II, table 2).

On the other hand, lag regressions do not provide evidence of past investment predicting present profits (table 2, panel III). The effect at lag zero is very strong and positive, but lagged effects of investment on profits are not significant and even have "the wrong

\footnotetext{
${ }^{9}$ Both investment and profits have trends and the augment Dickey-Fuller (ADF) test indicates that they have unit roots. However, they are stationary when transformed into rates of growth. Tests of cointegration do not indicate cointegration of investment and profits in levels.

${ }^{10}$ The model is $\dot{I}_{t}=\alpha+\sum_{k=0}^{5} \beta_{k} \cdot \dot{p}_{t-k}+\varepsilon_{t}$, where the superimposed dot indicates the rate of growth of the variable, $I$ is investment, $p$ is profits before taxes, $\varepsilon$ is the error term, and the subindex $t$ refers to time in quarters.
} 
sign." If past investment were determining present profits, we would expect significant and positive lag effects of investment on profits. However, the observed lag effects are negative, and not statistically significant.

\subsection{Granger-causality tests}

Results of Granger causality tests are quite sensitive to the procedure used to transform the series into stationary ones and to the number of lags included in the test regression (Hamilton, 1994). When many lags are included bidirectional Granger-causality is often found, with past profits helping to predict investment and past investment helping to predict profits. However, the hypothesis that profits before or after taxes do not help to predict investment (table 3, panels A and C) is rejected at very high levels of significance $(P<0.01$, with $P<0.001$ in many cases) in all lag specifications, while the hypothesis that investment does not help to predict profits often fails to be rejected at the $5 \%$ significance level. $P$-values obtained with the asymptotic test of Granger causality (not shown) are quite similar. Overall, causality from profits to investment is strongly supported by Granger tests at all lags, while that is not the case for causality from investment to profits.

\section{Discussion and conclusions}

From the point of view of statistical theory a hypothesis test starts with null and alternative hypotheses of scientific interest, and looks for whether there is evidence to reject the default null hypothesis in favor of the alternative. Statistically significant effects that are actually spurious can be chance findings, since in $5 \%$ of the tests we will find estimates that are statistically significant at the $95 \%$ level of confidence in spite that the null hypothesis is correct (that is, the effect is zero). Spurious statistical significance can be also found if methodological issues make the evidence against the null stronger than it actually. That can be the case when multiple hypotheses are tested at the same time. A Pvalue that is correct when computed for an individual test is "devalued" when it is computed for each one of multiple tests; formally, that is the case of $P$-values in Table 2. $P$ values are suspiciously small specially when the researcher computes multiple tests with a collection of different variables and then chooses those relationships that have shown statistical significance. Terms such as pre-testing bias or, more informally, data snooping, fishing expedition, or data mining have been used for that practice. The reader shall judge to what extent the $P$-values in Table 2 are subjected to that kind of bias. At any rate, the regressions there can be considered as descriptive-nothing more, and nothing less. Our claim is that the results of those regressions together with (a) the rates of growth of profits and investment (table 2) during different phases of the business cycle, (b) the results of Granger-causality tests (table 3), and (c) theoretical reasons, strongly support a causal effect of profits on investment. We found however little evidence if favor of causality in the other direction.

While Marx and Mitchell (MM) viewed profitability as the key variable determining the dynamic condition of the economy, with the level of profits primarily determined internally by the workings of the system, authors following the Keynesian-Kaleckian (KK) tradition view investment as depending on profits, but since profits depend themselves on previous investment, it is investment that ultimately rules the course of the economy. As Matthews noted, with entrepreneurs screwing themselves up to do enough investment, profits would eventually rise. This is as if entrepreneurs and owners of money in general were able to pull themselves up by their bootstraps. In a sense, supply would create its own demand, and Say's Law, tossed out the door, comes back in through the window. Furthermore, in the KK perspective a fluctuating economy occurs in which entrepreneurs' changing rates of investment set the future path for the economy. Investment and government spending are in this perspective the only two variables that set the fu- 
ture path of the economy. Were it not for human psychology determining investment, and ruling political forces determining Government spending, there would be no recessions. Then, shouldn't we consider the KK perspective as an exogenous theory of the cycle?

On the other hand, in the MM perspective profits determine investment, and investment determines expansions and recessions, and we have a system in which profits are the major variable that determines its dynamics. To state that we have a profit-led economy (Barbosa-Filho and Taylor, 2006; Rada and Taylor, 2006; Mohun and Veneziani, 2008) probably amounts to something similar. The existence of significant hoards of money during economic crisis has been recently highlighted (Wilson 2009, Dash and Schwartz 2011) and it seems then that the conversion of these hoards of money into revenue-producing (and job-producing) investment is a key element for getting the economy out of a slump. But for this to occur, the rise in profitability is a key issue. The destruction of existing capital (by bankruptcies and liquidations) that reduces competition and allows for purchases of capital goods at liquidation prices, coupled with the fall in wages, contribute to create renewed opportunities for the investment of liquid money required for recovery. But those owning banks or big enterprises don't want to hear about destruction of financial capital as a key element to overcoming the crisis, and those earning their income as wages prefer to believe the story that rising wages will create more demand and will lead the economy toward recovery.

These are however theoretical and political implications that can be put aside. What for scientific purposes must not be put aside is the statistical evidence that raises serious doubts about the hypothesis that investment is "the key variable," that investment, as Minsky put it, calls the tune.

The results of the present investigation should not be particularly surprising, since the role of profitability as the major determinant of investment has been found previously by others (Bhaskar and Glyn, 1995; Blanchard, Rhee and Summers, 1993). One of the key findings of Tinbergen's early econometric studies on the business cycle was precisely that profits are the major determinant of investment (Tinbergen, 1939). But in an episode that highlights the always present anti-empirical bent of economics, Tinbergen's pioneering investigations received heavy criticism from none other than Lord Keynes and the nascent figure of the anti-Keynesian field, Milton Friedman (Morgan, 1990). Even a major econometrician and theorist of the business cycle, Richard Goodwin, attempted to downplay the importance of Tinbergen's conclusion asserting that "if we reverse the direction of causality and say that investment determines profits through the multiplier and income, we rob one of Tinbergen's chief results of much of its significance". Goodwin argued that "in the cycle most things go up and down together, and hence the danger of spurious correlation is very great" (Goodwin, 1964:433). While this indeed is true, it is possible to extend the analysis further. Though profits, investment, wages, output, and other variables swing up and down "together" in expansions and recessions, observed lags and statistical analysis show that the two potential directions of causation between investment and profits are not equally likely. The hypothesis that profits determine investment is much more consistent with the empirical evidence. If investment "calls the tune," then that tune is an echo of a previous melody.

\section{Acknowledgements}

This text has benefitted from comments and observations by Elena Gouskova, Paul Mattick, Rolando Astarita, Anwar Shaikh, Duncan Foley, Ed Ionides, Wallace Genser, Paul Zarembka, and anonymous reviewers. The usual disclaimers apply. 
Figure 1. Corporate profits and investment, quarterly data since 1999 to the Great Recession. Dark areas are recessions according to the NBER chronology

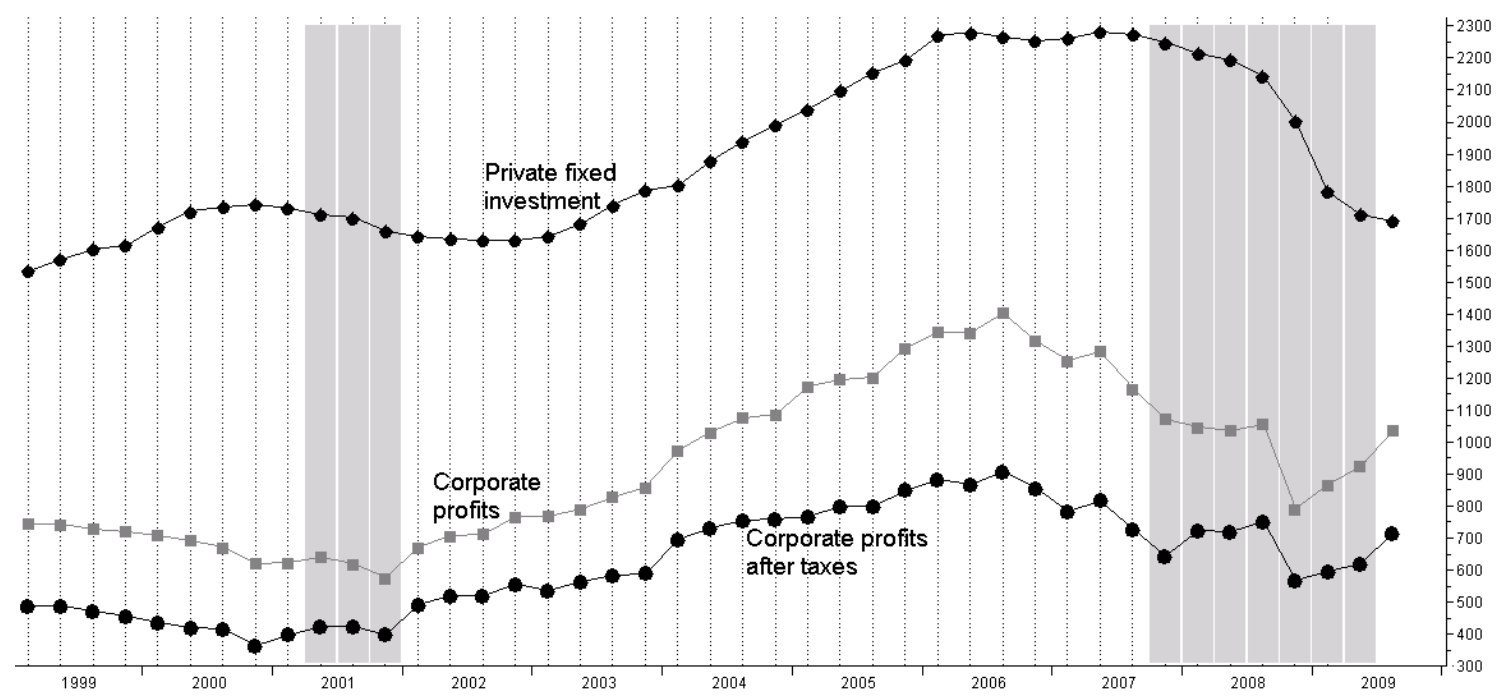

Data from the Bureau of Economic Analysis (NIPA Tables 5.1 and 5.3.5), in billions of dollars, seasonally adjusted at an annual rate (SAAR).

Figure 2. Corporate profits (before and after taxes) and fixed investment as a share of gross domestic income, quarterly data since 1947 to the Great Recession

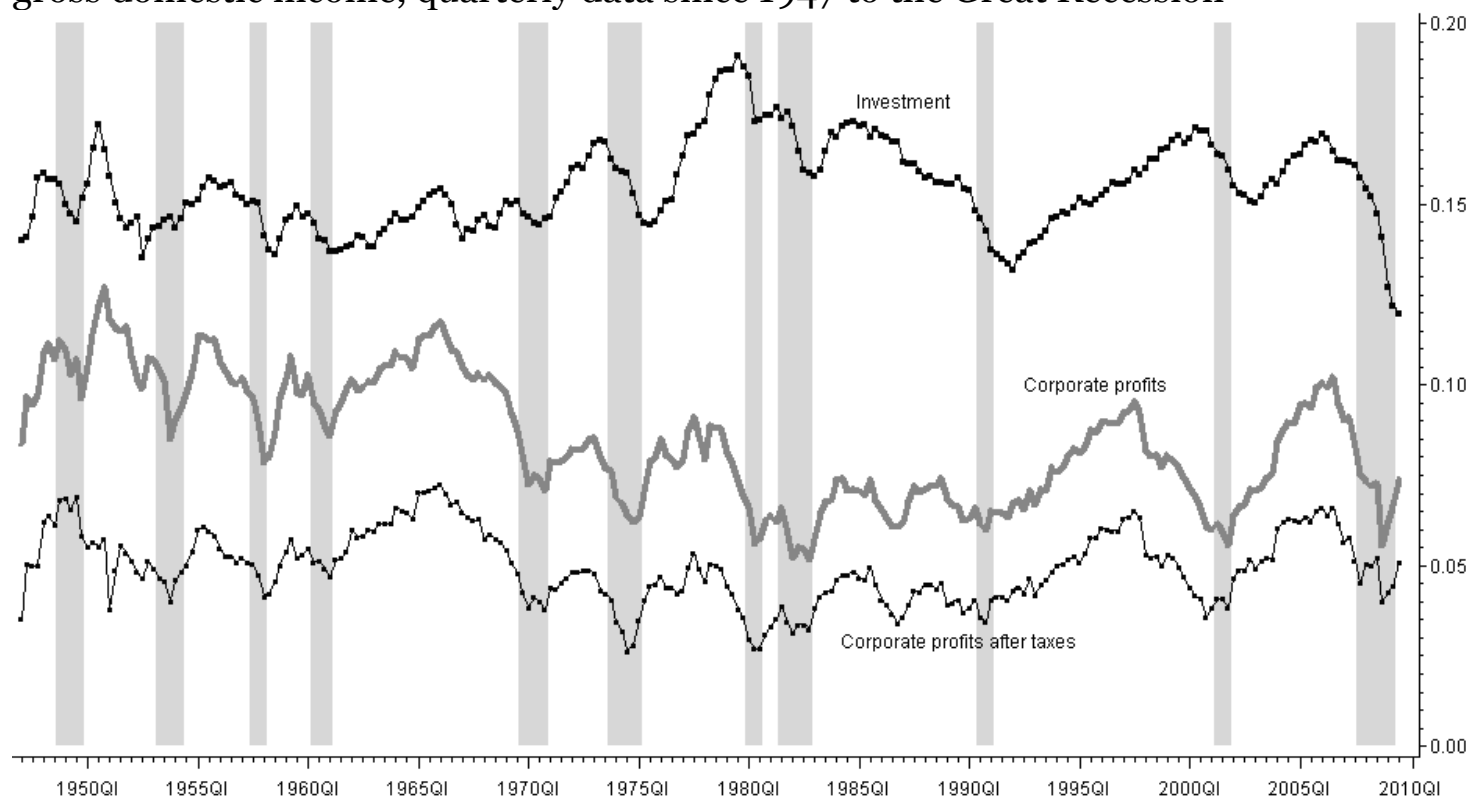

Computed with NIPA data (U.S. Bureau of Economic Analysis, www.bea.gov) and the business cycle chronology of the National Bureau of Economic Research, assuming a recession lasts from the peak quarter to the trough quarter, and both quarters are included in it. 
Table 1. Quarterly rates of growth (\%) of profits, investment, and wages and salaries during the recessions and expansions of 251 quarters of the U.S. economy (1947:I to 2009:III).

\begin{tabular}{|c|c|c|c|c|c|c|}
\hline \multirow[b]{2}{*}{$\begin{array}{l}\text { Sample } \\
\text { (quarters) }\end{array}$} & \multicolumn{2}{|c|}{ Profits } & \multirow{2}{*}{$\begin{array}{r}\text { Private } \\
\text { fixed in- } \\
\text { vestment }\end{array}$} & \multicolumn{2}{|c|}{ Wages \& salaries } & \multirow[b]{2}{*}{$\begin{array}{c}\text { Sample size } \\
\text { (quarters) }\end{array}$} \\
\hline & $\begin{array}{r}\text { before } \\
\text { taxes }\end{array}$ & $\begin{array}{l}\text { after } \\
\text { taxes }\end{array}$ & & & $\begin{array}{r}\text { with supple- } \\
\text { ments }\end{array}$ & \\
\hline All & 0.7 & 0.9 & 0.7 & 0.7 & 0.8 & 251 \\
\hline Expansion & 1.9 & 1.9 & 1.3 & 1.0 & 1.1 & 201 \\
\hline Recession & -3.9 & -3.1 & -1.3 & -0.4 & -0.2 & 50 \\
\hline Recession -8 & 0.4 & 3.0 & 0.6 & 0.7 & 0.8 & 9 \\
\hline Recession -7 & 4.3 & 4.4 & 2.2 & 1.8 & 1.8 & 10 \\
\hline Recession -6 & 1.7 & 2.5 & 0.7 & 1.1 & 1.1 & 10 \\
\hline Recession -5 & -0.4 & -0.1 & 0.2 & 1.0 & 1.0 & 10 \\
\hline Recession -4 & -0.8 & -0.9 & 0.8 & 1.0 & 1.0 & 10 \\
\hline Recession -3 & -0.4 & -0.4 & 0.6 & 1.1 & 1.1 & 11 \\
\hline Recession -2 & 0.2 & 0.2 & 0.9 & 1.0 & 1.1 & 11 \\
\hline Recession -1 & -1.9 & -0.8 & -0.2 & 0.7 & 0.8 & 11 \\
\hline Trough & -2.5 & -0.7 & -0.8 & -0.8 & -0.6 & 11 \\
\hline Trough +1 & 9.3 & 10.9 & 3.7 & 0.7 & 0.8 & 11 \\
\hline Trough +2 & 7.1 & 6.3 & 2.5 & 1.3 & 1.4 & 10 \\
\hline Trough +3 & 4.9 & 4.7 & 2.2 & 1.2 & 1.2 & 10 \\
\hline
\end{tabular}

Note: Recessions defined as including both the peak quarter and the trough quarter in the NBER chronology, and all quarters between a peak and the next trough. "Recession -8" means the sample including the expansion quarters preceding recession by 8 quarters; "Trough +2 " means the sample including the second quarters after the end of the recession, etc. All rates of growth computed with variables adjusted for inflation by transforming nominal figures from NIPA data into 2005 dollars. 
Table 2. Results of regressions to estimate private fixed investment as a function of corporate profits or vice versa

\begin{tabular}{|c|c|c|c|c|c|c|c|}
\hline \multicolumn{8}{|c|}{ Panel I.-Private fixed investment regressed on corporate profits } \\
\hline Lag & A & $\mathrm{B}$ & $\mathrm{C}$ & $\mathrm{D}$ & $\mathrm{E}$ & $\bar{F}$ & $\mathrm{G}$ \\
\hline $\mathrm{O}$ & $0.77^{* * *}$ & $0.67^{* * *}$ & $0.67^{* * *}$ & $0.66^{* * *}$ & $0.68^{* * *}$ & $0.70^{* * *}$ & $0.70^{* * *}$ \\
\hline 1 & & $0.65^{* * *}$ & $0.60^{* * *}$ & $0.61^{* * *}$ & $0.59^{* * *}$ & $0.61^{* * *}$ & 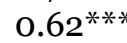 \\
\hline 2 & & & $0.32^{* * *}$ & $0.29 * * *$ & $0.29^{* * *}$ & $0.26 * *$ & $0.27^{* *}$ \\
\hline 3 & & & & $0.18^{*}$ & 0.15 & 0.16 & 0.15 \\
\hline 4 & & & & & 0.15 & 0.10 & 0.10 \\
\hline 5 & & & & & & $0.26 * *$ & $0.25^{* *}$ \\
\hline 6 & & & & & & & 0.06 \\
\hline$R^{2}$ & 0.22 & 0.37 & 0.40 & 0.42 & 0.42 & 0.44 & 0.44 \\
\hline
\end{tabular}

Panel II.- Private fixed investment regressed on profits after taxes

\begin{tabular}{|c|c|c|c|c|c|c|c|}
\hline Lag & $\mathrm{A}$ & B & $\mathrm{C}$ & $\mathrm{D}$ & $\mathrm{E}$ & $\mathrm{F}$ & G \\
\hline O & $0.43^{* * *}$ & $0.35^{* * *}$ & $0.35^{* * *}$ & $0.34^{* * *}$ & $0.36^{* * *}$ & $0.37^{* * *}$ & $0.37^{* * *}$ \\
\hline 1 & & $0.49^{* * *}$ & $0.45^{* * *}$ & $0.46^{* * *}$ & $0.44^{* * *}$ & $0.47^{* * *}$ & $0.48^{* * *}$ \\
\hline 2 & & & $0.24^{* *}$ & $0.22^{* *}$ & $0.23^{* *}$ & $0.21^{*}$ & $0.23^{* *}$ \\
\hline 3 & & & & 0.14 & 0.12 & 0.13 & 0.11 \\
\hline 4 & & & & & 0.12 & 0.10 & 0.12 \\
\hline 5 & & & & & & $0.18^{*}$ & $0.15^{*}$ \\
\hline 6 & & & & & & & $0.20^{* *}$ \\
\hline$R^{2}$ & 0.10 & 0.23 & 0.26 & 0.27 & 0.28 & 0.29 & 0.32 \\
\hline
\end{tabular}

Panel III.- Corporate profits regressed on private fixed investment

\begin{tabular}{lccccccc}
\hline Lag & $\mathrm{A}$ & $\mathrm{B}$ & $\mathrm{C}$ & $\mathrm{D}$ & $\mathrm{E}$ & $\mathrm{F}$ & $\mathrm{G}$ \\
\hline $\mathrm{O}$ & $0.28^{* * *}$ & $0.35^{* * *}$ & $0.36^{* * *}$ & $\mathbf{0 . 3 5 ^ { * * * }}$ & $0.35^{* * *}$ & $0.35^{* * *}$ & $0.35^{* * *}$ \\
1 & & $-0.13^{* *}$ & $-0.09^{*}$ & $-\mathbf{0 . 0 8}$ & -0.08 & -0.08 & -0.08 \\
2 & & & $-0.10^{* *}$ & $-\mathbf{0 . 0 4}$ & -0.03 & -0.03 & -0.03 \\
3 & & & $-\mathbf{o . 1 3}^{* *}$ & $-0.11^{*}$ & -0.11 & -0.11 \\
4 & & & & & -0.05 & -0.04 & -0.04 \\
5 & & & & & & -0.02 & -0.02 \\
6 & & & & & & & -0.01 \\
$R^{2}$ & 0.22 & 0.25 & 0.27 & 0.31 & 0.31 & 0.31 & 0.31 \\
\hline
\end{tabular}

$\dagger P<0.1 \quad{ }^{*} P<0.05 \quad{ }^{* *} P<0.01 \quad{ }^{* * *} P<0.001$.
Notes: The explanatory variable is included in the regression at lag 0 only in specification $\mathrm{A}$, at lags $\mathrm{O}$ and 1 in specification $\mathrm{B}$, and so on and so forth; until specification $\mathrm{G}$ in which the covariate is included in the regression at lags $0,1,2, \ldots$ until 6 . Variables are quarterly rates of change computed from inflation-adjusted SAAR data for private fixed investment and corporate profits before and after taxes. Parameter estimates highlighted in boldface correspond to the specification that minimizes AIC in the panel. Specifications including up to 20 lags were tested (in specifications with more than six lags no significant coefficients were found beyond a few that are to be expected by chance). 
Table 3. Granger causality tests for profits and private fixed investment. Each panel indicates the null hypothesis, the number of lags included in the test and the P-value (testing series either in rate of change or in first differences)

\begin{tabular}{|c|c|c|c|}
\hline Null hypothesis & Lags & $\begin{array}{l}\text { Rate of } \\
\text { change }\end{array}$ & $\begin{array}{r}\text { First } \\
\text { differences }\end{array}$ \\
\hline \multirow{9}{*}{$\begin{array}{l}\text { A.- Profits before } \\
\text { taxes do not help to } \\
\text { predict investment }\end{array}$} & 15 & $<0.001$ & $<0.001$ \\
\hline & 12 & $<0.001$ & $<0.001$ \\
\hline & 10 & $<0.001$ & $<0.001$ \\
\hline & 7 & 0.001 & $<0.001$ \\
\hline & 5 & $<0.001$ & $<0.001$ \\
\hline & 4 & 0.001 & $<0.001$ \\
\hline & 3 & $<0.001$ & $<0.001$ \\
\hline & 2 & $<0.001$ & $<0.001$ \\
\hline & 1 & $<0.001$ & $<0.001$ \\
\hline \multirow{9}{*}{$\begin{array}{l}\text { B.- Investment does } \\
\text { not help to predict } \\
\text { profits before taxes }\end{array}$} & 15 & 0.011 & $<0.012$ \\
\hline & 12 & 0.125 & 0.058 \\
\hline & 10 & 0.011 & 0.044 \\
\hline & 7 & 0.014 & 0.009 \\
\hline & 5 & 0.047 & 0.004 \\
\hline & 4 & 0.017 & 0.004 \\
\hline & 3 & 0.001 & 0.005 \\
\hline & 2 & 0.169 & 0.170 \\
\hline & 1 & 0.310 & 0.678 \\
\hline \multirow{9}{*}{$\begin{array}{l}\text { C.- Profits after } \\
\text { taxes do not help to } \\
\text { predict investment }\end{array}$} & 15 & $<0.001$ & $<0.001$ \\
\hline & 12 & 0.001 & $<0.001$ \\
\hline & 10 & $<0.001$ & $<0.001$ \\
\hline & 7 & 0.001 & $<0.001$ \\
\hline & 5 & 0.001 & $<0.001$ \\
\hline & 4 & 0.005 & $<0.001$ \\
\hline & 3 & 0.002 & $<0.001$ \\
\hline & 2 & 0.001 & $<0.001$ \\
\hline & 1 & $<0.001$ & $<0.001$ \\
\hline \multirow{9}{*}{$\begin{array}{l}\text { D.- Investment does } \\
\text { not help to predict } \\
\text { profits after taxes }\end{array}$} & 15 & 0.005 & 0.019 \\
\hline & 12 & 0.150 & 0.049 \\
\hline & 10 & 0.064 & 0.018 \\
\hline & 7 & 0.079 & 0.014 \\
\hline & 5 & 0.097 & 0.041 \\
\hline & 4 & 0.082 & 0.059 \\
\hline & 3 & 0.008 & 0.027 \\
\hline & 2 & 0.068 & 0.061 \\
\hline & 1 & 0.851 & 0.811 \\
\hline
\end{tabular}

Note: The series of profits and fixed private investment figures were SAAR and inflation-adjusted quarterly data from 1947:II to 2009:III. 


\section{References}

Adelman, I. (1960). Business cycles-Endogenous or stochastic? Economic Journal 70, 783-796.

Asimakopulos, A. (1977). Profits and investment: A Kaleckian approach. In: Harcourt, G. C. (ed.), The Microeconomic Foundations of Macroeconomics: Proceedings of a Conference held by the IEA. London, Macmillan, pp. 328-372.

Barbosa-Filho, N. H. \& Taylor, L. (2006). Distributive and demand cycles in the US economy: A structuralist Goodwin model. Metroeconomica 57(3):389.

Besomi, D. (2005). Clément Juglar and the transition from crises theory to business cycle theories [Paper prepared for a conference on the occasion of the centenary of the death of Clément Juglar, Paris, 2 December 2005] www.unil.ch/webdav/site/cwp/users/neyguesi/public/D._Besomi_

Bhaduri, A. \& Marglin, S (1990). Unemployment and the real wages: the economic basis for contesting political ideologies. Cambridge Journal of Economics 14:375-393.

Bhaskar, V. \& Glyn, A. (1995). Expectations and investment: an econometric defense of animal spirits. In: Epstein, G. A., Gintis, H, eds. Macroeconomic policy after the conservative era: Studies in investment, saving and finance. Cambridge University Press, pp. 197-223.

Blanchard, O., Rhee, C. \& Summers, L. (1993). The Stock Market, Profit, and Investment. Quarterly Journal of Economics 108:115-136.

Boddy, R. \& Crotty, J. (1975). Class Conflict and Macro-Policy: The Political Business Cycle. Review of Radical Political Economics 7:1-19.

Boldrin, M. \& Horvath, M. (1995). Labor Contracts and Business Cycles." Journal of Political Economy 103:972-1004.

Burns, A. F. \& Mitchell, W. C. (1946). Measuring business cycles. New York: National Bureau of Economic Research.

Dash, E., Schwartz, N.D. (2011). Banks flooded with cash they can't profitably use. New York Times, October 24 (Business, p. 1).

Devine, J. N. (1986). Empirical studies in Marxian crisis theory: Introduction. Review of Radical Political Economics 18:1-12.

Frisch, R. (1933). Propagation problems and impulse problems in dynamic economics. Oslo, Universitetets Økonomische Institutt.

Glasner, D. \& Cooley, T. F., eds. (1997). Business cycles and depressions: An encyclopedia. New York: Garland.

Goodwin, R. M. (1964). Econometrics in business-cycle analysis. In: Hansen (1964), pp. 417-468.

Gordon, R. A (1961). Business fluctuations, 2nd ed. New York: Harper.

Haberler, G. (1960). Prosperity and depression: A theoretical analysis of cyclical movements, 4th ed. Cambridge: Harvard University Press.

Hall, T. E. (1990). Business cycles: The nature and causes of economic fluctuations. New York: Praeger.

Hamilton, J. D. (1988). A neoclassical model of unemployment and the business cycle. Journal of Political Economy 96:593. . Time Series Analysis. Princeton, NJ: Princeton University Press, 1994.

Hansen, A. H. (1964). Business cycles and national income, 2nd ed. London: George Allen and Unwin. . (1949). Wesley Mitchell, Social Scientist and Social Counselor. Review of Economics and Statistics 31:245.

Huntington, E. (1920). World-power and Evolution. New Haven: Yale University Press.

Kalecki, M. (1971). Selected Essays on the Dynamics of the Capitalist Economy 1933-1970. Cambridge, Cambridge University Press. (1990). Collected Works of Michal Kalecki. Volume I: Business Cycles and Full Employment (Jerzy Osiatinsky, ed; C. A. Kisiels, transl). Oxford: Clarendon Press. (1991). Collected Works of Michal Kalecki. Volume II: Capitalism: Economic Dynamics (Jerzy Osiatinsky, ed; C. A. Kisiels, transl.). Oxford: Clarendon Press.

Keynes, J. M. (1936). The general theory of employment, interest, and money. London: Macmillan. 
(1937). The General Theory of Employment. Quarterly Journal of Economics, 51(2):209223.

Knoop, T. A. (2004). Recessions and depressions: Understanding business cycles. Westport, Conn.: Praeger.

Koopmans, T. C. (1947). Measurement without theory. Review of Economic Statistics 29:161-172.

Marx, K. (1968). Theories of Surplus-Value (Volume IV of Capital) [1863]. Moscow: Progress Publishers. . (1977). Capital - A critique of political economy [1867]. Vol. I, transl. by B. Fowkes. New York: Vintage Books. (1981). Capital - A critique of political economy [1894]. Vol. III, ed. by F. Engels and tr. by D. Fernbach. New York: Vintage Books.

Matthews, R. C. O. (1959). The business cycle. Chicago: University of Chicago Press.

Minsky, H. P. (2008). Stabilizing an unstable economy [1986]. New York: McGraw-Hill. . (1991). The financial instability hypothesis: A clarification. In The risk of economic crisis. M. Feldstein, ed., Chicago: University of Chicago Press, pp. 158-166.

Mitchell, W. C. (1913). Business cycles. Berkeley: University of California Press. . (1927). Business Cycles: The Problem and its Setting. New York: National Bureau of Economic Research.

. (1941). Business cycles and their causes: A new edition of Mitchell's Business Cycles, Part III. Berkeley: University of California Press. . (1951). What happens during business cycles: A progress report. New York: National Bureau of Economic Research.

Mohun, S. \& Veneziani, R. (2008). Goodwin cycles and the U.S. economy, 1948-2004. In Mathematical economics and the dynamics of capitalism: Godwin's legacy continued. P. Flaschel and M. Landesmann, eds. New York: Routledge, pp. 107-130.

Morgan, M. S. (1990). The history of econometric ideas. Cambridge: Cambridge University Press.

Ohanian, L. E. (2008). Back to the Future with Keynes. Federal Reserve Bank of Minneapolis Quarterly Review 32:10-16.

Pigou, A. C. (1927). Wage policy and unemployment. Economic Journal 37:355.

Rada, C. \& Taylor, L. (2006). Empty Sources of Growth Accounting, and Empirical Replacements à la Kaldor with Some Beef. Structural Change \& Economic Dynamics 17: 487-500.

Robinson, J. (1979). The Generalisation of the General Theory, and Other Essays. London: Macmillan.

Schumpeter, J. A. (1954). History of economic analysis. London: Allen \& Unwin.

Shackle, G. L. S. (1967). The years of high theory: Invention and tradition in economic thought 1926-1939. Cambridge: Cambridge University Press.

Sherman, H. J., \& Kolk, D. X. (1997). Business cycles and forecasting. New York: Addison-

Wesley.

Steindl, J. (1991). Some comments on the three versions of Kalecki's Thoery of the Trade Cycle. In Kalecki 1991, pp. 597-604.

Targetti, F. \& Kinda-Hass, B. (1982). Kalecki's review of Keynes's General Theory. Australian Economic Papers Vol. 21, No. 38, pp. 244-60.

Tinbergen, J. (1939). Statistical Testing of Business-Cycle Theories: Volume II - Business Cycles in the United States of America 1919-1932. Geneva: League of Nations.

Wilson, M. (2009). Sales of Safes Boom as the Economy Falters: Looking for Security in a Cube of Steel. New York Times, March 6. 